\title{
Tools for Reconciling Professional and Personal Roles in Poland. Challenges and Barriers
}

\author{
ŁUKASZ SIENKIEWICZ \\ Institute of Human Capital, Collegium of Business Administration, \\ SGH Warsaw School of Economics
}

\begin{abstract}
One of the key challenges faced by today's workers is to live at an ever-increasing pace, which creates a conflict between professional and private life. This results from the extension and intensification of working time, the need for constant improvement of competences and, as a result, lack of free time for family life or rest. More and more companies are opting for specialised programmes to prevent imbalances between professional and private life (Work-Life Balance - WLB). However, the scope of solutions applied by Polish employers is not systematically examined. Therefore, the article reviews and analyses the applied solutions in the field of reconciliation of professional and personal life (including family life) in enterprises operating in Poland, as well as barriers and challenges of their implementation. Identified challenges of financial, legislative, organisational and cultural character limit the practical use of such mechanisms.
\end{abstract}

Keywords: work-life balance, professional and personal roles, working conditions

JEL Classification Codes: M540, J530, J810 


\section{Introduction}

One of the key challenges facing today's employees is to live at an ever-increasing pace. This results from the extension and intensification of working time, the need for constant improvement of competences and, as a result, lack of free time for family life or rest. One can, therefore, speak of a specific 'invasion' of work into the sphere of personal life (Sadowska-Snarska, 2007). This creates an inevitable conflict between professional and private life (including family life), since the requirements imposed on an individual in one of these areas affect adversely his or her ability to meet the requirements of the other area (Greenhaus \& Beutell, 1985). There are 3 components of the WLB: time (devoting time to professional and family responsibilities), commitment (both to work and to family life), satisfaction (with work and family life) (Greenhouse et al., 2003, as cited in Hildt-Ciupińska, 2014).

When competing on the global or international market, Polish employers are subject to constant competitive pressure, which often leads them to reducing costs by extending the working time of their employees and assigning them an excessive number of tasks. Employees often conform to such decisions for fear of losing their jobs. Research conducted in Poland (Głogosz, 2011) shows that a significant proportion of people employed in Polish enterprises face difficulties in reconciling their professional and personal lives. $79 \%$ of the respondents thought that they spent too much time on work, more than half (56\%) declared that it was difficult for them to adjust working time to family duties, while $43.7 \%$ had problems with adjusting it to childcare and $33.2 \%$ to the care of elderly family members. The most important factors increasing the risk of a conflict between work and other spheres of the employee's life include strong involvement in the role, lack of social support, personality traits, characteristics of the workplace and demographic traits (Michel et al., 2011).

Due to the intensification of these negative phenomena and their consequences not only for employees but also for enterprises, there is a growing interest in worklife balance (WLB) solutions. Balance of work and life covers the whole area of human activity outside work, including family life (caring for children and other dependants), social life (e.g. maintaining relationships with other people) and personal life (e.g. caring for health, hobbies, recreation) (Hildt-Ciupińska, 2014). In the context of family life, the work-life balance is defined as the degree to which a person is engaged and satisfied with both his/her professional and family life (Hildt-Ciupinska, 2014).

In connection with the above observations, the aim of the article is to review and analyse the applied solutions in the field of reconciliation of professional and personal life (including family life) in enterprises operating in Poland, as well as 
barriers and challenges of their implementation. This will create the possibility of increasing its effectiveness as well as its wider use in the Polish society. In particular, the article focuses on the analysis of the following issues:

1. What are the main negative consequences of the work-life (including family life) imbalance in Poland?

2. What solutions for reconciling professional and personal (including family) roles are applied in Polish enterprises?

3. What are the main challenges and barriers to the implementation of these solutions?

\section{Consequences of the imbalance between professional and private life in Poland}

The dominance of professional activity in life leads to many negative phenomena, and as a consequence, the long-term imbalance between work and life is unfavourable for both employees and employers. There is a link between a large work-life conflict and physical and mental health, poor quality of life, high levels of stress, a sense of the lack of control over work. (Bryson, 2007, as cited in Hildt-Ciupińska, 2014), as well as low involvement in physical activity and more frequent consumption of alcohol (White \& Buckley, 2007, as cited in Hildt-Ciupińska, 2014). Often after returning home from work, a person is too tired to take on household responsibilities and has permanent difficulties with family responsibilities (Blessing, 2008).

Long-term imbalance may result in negative consequences at three levels (Table 1). Growing problems of the employed translate into the quality of their work, consequently, leading to the deterioration of the condition of the enterprise, thus influencing, at the macro scale, the social and economic situation of the country.

In view of the broad negative consequences of work-life imbalance - not only for employees and enterprises, but also for the economy - these issues are also of concern to decision-makers at the European Union level. On 13 June 2019, the Council of the European Union adopted a directive on the work-life balance of parents and carers. The directive provides for measures to adopt flexible working arrangements, to share parental leave between mother and father, to encourage the use of paternity and carers' leave.

The introduction of solutions to reconcile professional and personal roles is becoming increasingly common at the enterprise level as well. In terms of company activities, the WLB is defined as such organisational activities (e.g. flexible working hours, teleworking, childcare at the workplace) that facilitate the reconciliation of professional and non-professional duties, i.e. the aforementioned care of dependent 
persons, but also personal life, own hobbies, leisure or recreation (Darcy et al., 2012, as cited in Hildt-Ciupińska, 2014).

Table 1. Negative consequences of an imbalance between work and private life

\begin{tabular}{|c|c|c|}
\hline $\begin{array}{l}\text { For macro-scale societies } \\
\text { (national, regional, etc.) }\end{array}$ & For organisations & $\begin{array}{c}\text { For employees, as well as for } \\
\text { the unemployed and excluded } \\
\text { and their families }\end{array}$ \\
\hline $\begin{array}{l}\text { - declining birth rates, } \\
\text { - postponement of the birth } \\
\text { of the first child, } \\
\text { - increasing number of } \\
\text { divorces, } \\
\text { - growing number of single- } \\
\text { parent families, } \\
\text { - growing social inequalities, } \\
\text { - unemployment, } \\
\text { - increasing incidence of } \\
\text { heart disease, cancer and } \\
\text { neurological disorders, } \\
\text { - insufficient childcare } \\
\text { and a growing number of } \\
\text { pathologies among children. }\end{array}$ & $\begin{array}{l}\text { - absenteeism, especially sick } \\
\text { leaves, } \\
\text { - increase in turnover; loss } \\
\text { of investment in human } \\
\text { capital, } \\
\text { - lower engagement at work, } \\
\text { - stress, } \\
\text { - lower concentration at work } \\
\text { and lower productivity, } \\
\text { - lower return on investments } \\
\text { in human capital, } \\
\text { - worse customer relations } \\
\text { and a more frequent loss of } \\
\text { customers, } \\
\text { - lower creativity and } \\
\text { innovation. }\end{array}$ & $\begin{array}{l}\text { - stress, } \\
\text { - deterioration of health, } \\
\text { including mental health, } \\
\text { - family conflicts, } \\
\text { - worse childcare, } \\
\text { - divorce, } \\
\text { - alcoholism, } \\
\text { - drug addiction, } \\
\text { - nicotine addiction, } \\
\text { - eating disorders, } \\
\text { - the decline in his/her value } \\
\text { - } \text { fam an employee, } \\
\text { family and work insecurity. }\end{array}$ \\
\hline
\end{tabular}

Source: Borkowska (2003, p. 16).

\section{Solutions for reconciling professional and personal roles applied in Polish enterprises}

Among the many different possibilities for effective reconciliation of professional and private life, one can distinguish basic organisational principles, which help to better match these two spheres. Numerous international and national studies show that these include childcare organisation, elderly care organisation, parental leave for working mothers and fathers, incentives for fathers to increase their participation in family life, flexible work organisation (Guereiro et al., 2007, as cited in Hildt-Ciupińska, 2014). The most valued solutions conducive to a less conflicting combination of family and professional responsibilities were the following: convenient location of a kindergarten close to home/work (53\%), high salaries (52.2\%) and easy and quick access to the workplace (49\%) (Muczyński, 2013).

This is further analysed in other available studies conducted in Poland. Research conducted on a sample of 210 small and medium-sized enterprises in 2008 on the potential assistance from the surveyed companies for various categories of employees 
within the framework of activities enabling reconciliation of personal and professional life showed that almost half (44.8\%) of the employers were particularly willing to help those employees who decided to supplement their knowledge in various forms. In addition, one in five employers, on average, declared to help employees who find it difficult to reconcile work and caring for young children. Another category of employees who could count on support among $11 \%$ of the surveyed companies were single parents of children, while only less than $8 \%$ of enterprises were willing to help employees whose work is connected with frequent stays away from home (Rogozińska-Pawełczyk \& Kołodziejczyk-Olczak, 2008).

The observation of the practice of Polish enterprises indicates that among the mechanisms mitigating the conflict between professional and personal duties, which are most often offered to the employed, one can distinguish (Głogosz, 2011):

- co-financing or financing: employee holidays, children's summer camps, kindergarten care, layettes for children (school-aged and newborns), holiday gifts for children, gift vouchers;

- flexible working time: flexible start and end time, part-time work, extra days off, dismissals to take care of personal matters (often used in small companies), granting leave at the time convenient to the parent (school holidays);

- health care services: private medical care for employees and their families, subsidised stay in a sanatorium, financed preventive medical check-ups and vaccinations for the family of the employee;

- assistance in difficult life situations: psychological and legal support;

- organisation of company events addressed to employees and their families: holidays, picnics.

In a survey conducted for the needs of the study Reconciliation mechanisms of professional and family roles in Polish enterprises (2016), concerning the implementation of mechanisms for reconciliation of professional and family roles in Polish enterprises, ${ }^{1}$ employees indicated particular solutions existing in their enterprises and assessed to what extent they are important for them in terms of facilitating reconciliation of professional and family roles. Collectively analysing the situation in the enterprises (number of responses $\mathrm{N}=515$ ) participating in the survey, the employees indicated the most frequent role reconciliation mechanisms: medical benefits for employees and their families (327 indications), flexible working time (298 indications), financial support for employees (275 indications) and flexible forms of work (225 indications). Medical services for employees and financial support is offered primarily

1 The report was prepared as part of the project titled: Family and work - it pays off!, run by the Ministry of Family, Labour and Social Policy (MRPiPS) under the EU's Fundamental Rights and Citizenship Programme, co-financed by the European Union. 
in medium-sized and large companies. This solution incurs increased costs for the company. Flexible working hours and flexible forms of work are used by companies regardless of all sizes. The only limitation is the internal work organisation (not all positions are fully flexible). The introduction of flexible working hours is a practically cost-free solution and is, therefore, very popular. In general, large companies provide more aid in the area of WLB than SMEs. Large enterprises also more often have formalised strategies or programmes for reconciling work and private roles than entities employing less than 250 people (Biuletyn..., 2015). Regardless of the scale of the company, the key determinant of undertaking WLB actions in the company is understanding the importance of this issue and the goodwill of the company's management (Rogozińska-Pawełczyk \& Kołodziejczyk-Olczak, 2008).

\section{Challenges and barriers to the implementation of solutions serving reconciliation of professional and personal roles in Polish enterprises}

The starting point for the introduction of programmes to facilitate the reconciliation of professional and personal roles should be a balanced organisational culture. We can talk about the evolution of the organisational culture towards a culture of balance between professional and personal life, from the observance of regulations, through the multiplication of ad hoc programmes, their coherence, up to full integration (Clutterbuck, 2005). The balance then becomes part of the philosophy and way of thinking and the impact of the programmes is fully understood by employees, managers and other interested parties (Borkowska, 2011). At the same time, it is crucial to raise awareness of the benefits of the implementation of role reconciliation mechanisms, which may, to some extent, reduce barriers to the implementation of the programmes, especially the difficulties in managing flexibility, the issue of maintaining the equality of all employees, or the lack of data on the evaluation of work-life programmes (Jones et al., 2006). Therefore, it is essential to understand the barriers and challenges of implementing and developing WLB programmes at the company level.

The most common barriers to the development of WLB programmes are (Riedmann, 2006):

- lack of knowledge about the possibilities of applying solutions for reconciling professional and private life;

- lack of informational and advisory support for the employee and the employer which would indicate benefits for both parties;

- errors in the organisation of work, in particular as regards excessive responsibilities and working time standards; 
- focusing on the reactions of employees and managers who are not covered by the programme and not on the benefits of those concerned.

Table 2. Barriers to the implementation of work-life programmes in enterprises in Poland

\begin{tabular}{|l|l|}
\hline Type of barriers & \multicolumn{1}{c|}{ Examples of challenges } \\
\hline Financial & $\begin{array}{l}\text { - adaptation of existing premises and workplaces (e.g. teleworking), } \\
\text { - hiring and training or only training of an employee responsible for the } \\
\text { implementation, monitoring and evaluation of practices, }\end{array}$ \\
\hline Legislative & $\begin{array}{l}\text { purchase of additional external services related to the implementation of } \\
\text { new WLB ideas (e.g. medical, supporting physical activity). }\end{array}$ \\
& $\begin{array}{l}\text { involvement of accountants in additional tasks and related activities. } \\
\text { employment contracts (e.g. in accordance with the regulations on } \\
\text { teleworking), }\end{array}$ \\
\hline imposition of additional responsibilities on persons performing managerial \\
functions with respect to work time recording (in accordance with the \\
provisions of the Labour Code), \\
- lack of supporting system solutions for employers employing older people \\
(50+), \\
the need to determine the schedule of working time in the case of flexible \\
working time, in accordance with the provisions of the Labour Code.
\end{tabular}

Source: own work based on Mechanizmy..., (2016).

In the study titled Mechanisms for reconciling professional and family roles in Polish enterprises (2016), the entrepreneurs and employees mentioned many challenges and equally many limitations, which make it difficult to apply interesting, effective for 
stakeholders and non-opposable WLB practices to economic activity. These barriers can be divided into financial, legislative, organisational and cultural (Table 2).

A vast majority of the surveyed enterprises report a lack of developed procedures and mechanisms of monitoring and control of the already implemented role reconciliation mechanisms. In connection with the rather common lack of transparency of rules, high degree of discretion in the solutions applied and intuitive choice of particular benefits, this is the weakest side of the practices currently functioning in Polish organisations (Mechanizmy..., 2016).

\section{Conclusion}

An important guideline for undertaking specific activities in relation to work-life balance is the awareness of negative consequences of imbalances. The lack of balance among employees often translates into lowering quality of their work, consequently leading to a deterioration of the company's condition and effectiveness, thus affecting the socio-economic situation of the country at a macro scale. Therefore, the awareness of challenges is crucial in establishing effective programmes for work-family roles reconciliation. Aware managers and business owners wanting to avoid negative consequences of the imbalance can take a number of short and long-term initiatives that should be tailored to the specific context of a given company.

Therefore, this first step should be a detailed analysis of employees' needs, matched with the financial and organisational possibilities of a given firm. The effectiveness of mechanisms of reconciling professional and family roles applied in enterprises is conditioned on adjusting them to the needs, expectations and values of employees. Meanwhile, as indicated by research conducted by the Institute of Labour and Social Affairs, most employers do not perform a diagnosis and thoughtlessly copy practices observed in other enterprises, guided only by the belief in their legitimacy and usefulness (Głogosz \& Machol-Zajda, 2011). Such an approach poses a threat to the implementation of misguided solutions, which will not only not reduce the difficulties in reconciling professional and family life for employees but may even contribute to their deepening. Needs of for example, parents (including single parents), persons taking care of other dependants (including the elderly or disabled), long-distance commuters, those representing different generations, might be significantly different.

Hence, the creation of supporting mechanisms must take into account the differentiated needs of the recipient groups. As such, it is impossible to enumerate best practice or one-size-fits-all solutions. However, in Poland there are some similarities among employees' expectations in terms of mechanisms for work-family 
life reconciliation. These can be attributed to unfulfilled social needs, like institutional care for children or dependants. Among the most appreciated initiatives supporting the work-life balance in Poland one can note childcare facilities (especially for preschool care), flexible working hours (due to commuting/traffic) or telework/work from home. Some of them are beyond the scope for employers (especially micro or small companies). However, less cumbersome and costly solutions should be considered for implementation as they constitute important support for workers.

\section{References:}

Biuletyn Rzecznika Praw Obywatelskich (2015). Zasada równego traktowania - Prawo i Praktyka nr 18. Godzenie ról rodzinnych i zawodowych. Równe traktowanie rodziców na rynku pracy. 7/2015, Warszawa: Biuro Rzecznika Praw Obywatelskich.

Borkowska, S. (2003). O równowagę między pracą i życiem: Unia Europejska - Polska. In: S. Borkowska (Ed.). Programy praca-życie a efektywność firm. Warszawa: Instytut Pracy i Spraw Socjalnych (IPiSS).

Borkowska, S. (Ed.) (2011). Programy praca - życie. Z teorii i praktyki. Warszawa: Instytut Pracy i Spraw Socjalnych (IPiSS).

Bryson, L., Warner-Smith, P, Brown, P, \& Fray, L. (2007). Managing the work-life roller-coaster: Privatestressor public healthissue? Social Science \& Medicine, 65, 1142-1153.

Clutterbuck, D. (2005). Równowaga między życiem zawodowym a osobistym. Przewodnik dla specjalistów do spraw personalnych. Kraków: Oficyna Ekonomiczna.

Darcy, C., McCarthy, A., Hill, J., \& Grady, G. (2012). Work-life balance: One size-fits-all? An exploratory analysis of the differential effects of career stage. European Management Journal, 30(2), 111-120.

Głogosz, D. (2008). Rezultaty programów praca-życie w krajach UE - korzyści dla pracowników i ich rodzin. In: C. Sadowska-Snarska (Ed.). Równowaga praca - życie - rodzina. Białystok: Wydawnictwo Wyższej Szkoły Ekonomicznej w Białymstoku.

Głogosz, D. (2011). Zatrudnienie przyjazne rodzinie - oczekiwania pracujących rodziców. In: C. Sadowska-Snarska, (Ed.). Godzenie życia zawodowego i rodzinnego w Polsce. Wydawnictwo Wyższej Szkoły Ekonomicznej w Białymstoku, Białystok.

Głogosz, D., \& Machol-Zajda, L. (2011). Zakłócenia równowagi praca-życie i ich skutki w opinii pracodawców. In: S. Borkowska (Ed.). Programy praca-życie. Z teorii i praktyki. Warszawa: IPiSS.

Greenhaus, H.J., Collins, M.K., \& Shaw, D.J. (2003). The relation between work-family balance and quality of life. Journal of Vocational Behaviour, 63, 510-531.

Greenhaus, J.H., \& Beutell, N.J. (1985). Sources of conflict between work and family roles. Academy of Management Review, 10/1985, 76-88. 
Guerreiro, D.M., Lourenco, I.V., \& Pereira, I. (2007). Good Practices for Reconciling Work and Family Life. Guide for Companies. Lisbon: Commission for Equality in Labour and Employment.

Hildt-Ciupińska, K. (2014). Work-life balance a wiek pracowników. Bezpieczeństwo Pracy - Nauka i Praktyka, nr 10, Warszawa: Centralny Instytut Ochrony Pracy - Państwowy Instytut Badawczy.

Jones, F., Burke, R.J., \&Westman, M. (Eds.) (2006). Work-life Balance. A Psychological Perspective. Hove and New Jork: Psychology Press.

Mechanizmy godzenia ról zawodowych i rodzinnych w polskich przedsiębiorstwach (2016). Instytut Analiz Rynku Pracy / Ministerstwo Rodziny, Pracy i Polityki Społecznej. Retrieved from: (https://rodzinaipraca.gov.pl/documents/8/raport_koncowy_wersja_ostateczna.pdf (5.1.2020).

Michel, J.S., Kotrba, L.M., Mitchelson, J., Clark, M.A., \& Baltes, B.B. (2011). Antecedents of work-family conflict: A meta-analytic review. Journal of Organizational Behavior, 32/2011, 689-725.

Muczyński, M. (2013). Godzenie życia zawodowego z rodzinnym jako element strategii CSR w przedsiębiorstwie. Przedsiębiorstwo we współczesnej gospodarce - teoria i praktyka nr 2. Gdańsk: Politechnika Gdańska.

Pluta, A. (2012). Problemy i możliwości godzenia zawodowego i prywatnego życia współczesnego człowieka. Management and Business Administration. Central Europe, 2(115), Warszawa: Wydawnictwo Akademii L. Koźmińskiego, 72-87.

Riedmann, A. (2006), Working time and work-life balance in European companies. Dublin: European Foundation for the Improvement of Living and Working Conditions.

Rogozińska-Pawełczyk, A., \& Kołodziejczyk-Olczak, I. (2008). Godzenie życia osobistego z pracą zawodową w firmach z sektora MŚP. In: C. Sadowska-Snarska, (Ed.). Równowaga praca-życie-rodzina. Białystok: Wydawnictwo Wyższej Szkoły Ekonomicznej w Białymstoku.

Sadowska-Snarska, C. (Ed.) (2007). Równowaga praca-życie. Studium porównawcze Finlandia - Polska - Hiszpania. Białystok: Wydawnictwo Wyższej Szkoły Ekonomicznej w Białymstoku.

White, D., \& Buckley, E. (2007). Adjust the Balance: Literature review Life Cycles and Work life Balance. Stoke on Trent: Centre for Health Psychology, Staffordshire University.

\section{Łukasz Sienkiewicz}

$\mathrm{PhD}, \mathrm{DSc}$ in the field of social sciences in the discipline of management and quality science, Associate Professor at the Institute of Human Capital at SGH Warsaw School of Economics. He specialises in human capital management and labour market issues. In the years 2012-2015, the leader of the Human Capital as an element of the enterprise value project, under which an innovative and unique 
in the country tool for measuring human capital was created. Author and co-author of over 80 peer-reviewed scientific publications (in the field of human capital measurement, competence management, job evaluation and assessment, career and talent management, strategic HRM and labour market) and over 80 expert opinions for the European Commission and economic practice.

e-mail address: 1sienk@sgh.waw.pl

ORCID: 000-0002-0653-8755 